http://dx.doi.org/10.17776/csj.79627

\title{
Zeytinli Ada İskelet Topluluğunun Diş ve Çene Patolojisi Açısından İncelenmesi
}

\author{
Saadet BIÇAK ${ }^{1}$ ve Fadime SUATA ALPASLAN ${ }^{1, *}$ \\ Cumhuriyet Üniversitesi Edebiyat Fakültesi Antropoloji Bölümü, Sivas
}

Received: 10.03.2015; Accepted: 20.03.2015

\begin{abstract}
Özet. Zeytinli ada, Balıkesir ili Erdek ilçesi sahiline yaklaşık olarak 250 metre uzaklıkta yer alıp 7900 metrekarelik bir alanı kapsar. Zeytinli ada arkeolojik buluntuları açısından oldukça zengin bir tarihe ve aynı zamanda da HelenRoma-Bizans ve Osmanlı dönemlerini içeren mozaik bir yapıya sahiptir. Çalışma materyalini, 2007-2011 yılları arasında gerçekleştirilen kazılar sonucunda ortaya çıkarılan 18 kadın, 37 erkek, 11 bebek ve çocuk, 60'ı cinsiyeti bilinmeyen olmak üzere toplam 126 bireye ait çene ve dişler oluşturmaktadır. Bireylere ait 467 diş üzerinde çürük, aşınma, apse, ölüm öncesi diş kaybı (antemortem), hypoplasia, alveol kaybı ve diş taşına bakılarak bunların bireylere ve cinsiyetlere göre dağılımları ortaya konulmaya çalışılmıştır.
\end{abstract}

Anahtar Kelimeler: Anadolu, Zeytinli Ada, Diş ve Çene, Patoloji, Helen, Roma, Bizans, Osmanlı

\section{The Analysies of Skeleton Group in Zeytinli Ada Teeth and Jaws of Pathology}

\begin{abstract}
Zeytinli ada, being far away almost 250 meters from the Coast of Erdekli in Balıkesir, takes in the area of $7900 \mathrm{sqm}$. Zeytinli Ada has a rich history in the view of archeological finds and also has a mosaic structure including the periods of Hellen-Rome- Byzantine and Ottoman. The study materials consist of jaws and teeth belonging to total 126 people ; 18 women, 38 men, 11 infants and children, 60 unknown sex having been come into existence in the result of excavations between 2007-2011 years. It is studied to determine the distribution according to the gender and individuals by examining decay, abrasion, abscess, the tooth loss before death (antemortem), hypoplasia, alveolar loss, and dental stone on 467 teeth belonging to individuals.
\end{abstract}

Keywords: Anatolia, Zeytinli Ada, Teeth and Jaws, Pathology, Hellen, Rome, Byzantine, Ottoman

\section{GíRiş}

Erdek (Balıkesir) ilçesi sınırları içerisinde yer alan Zeytinli ada, ismini üzerinde yer alan iki zeytin ağacından almaktadır (Resim 1). Zeytinli ada 1957'den 2006 y1lına kadar, eski adı beden terbiyesi şimdi ise gençlik spor müdürlüğü olarak bilinen kamu kurumu tarafından kamp ve dinlenme tesisi olarak kullanılmıştır. Kamp ve dinlenme tesisleri için sekiz blok inşa edilmiştir. Ancak bu yapıların altında 2300 yıllık bir tarihin varlığı keşfedilince Zeytinli ada sit alanı ve koruma planı çerçevesinde el değiştirmiş, tesisler yıkılmaya başlamış ve 2007 yılında kazılar başlatılmıştır.

\footnotetext{
*Corresponding author. Email: falpaslan@ cumhuriyet.edu.tr
} 


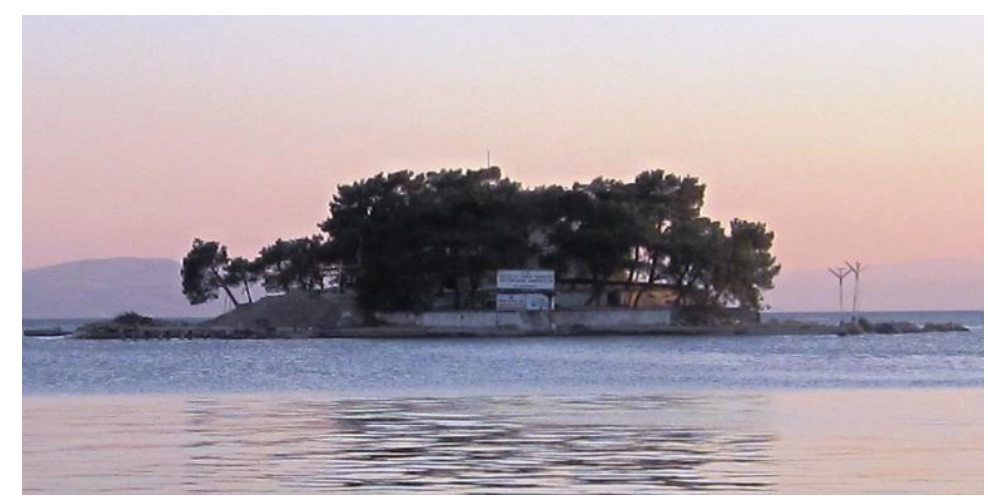

Resim 1. Zeytinli ada'nın genel bir görünümü.

Zeytinli ada küçük olmasına rağmen, arkeolojik bakımdan oldukça zengin tarihi eserler sunar. Ada kilisesi, Yeraltı kilisesi, Ayazma, Patrik hamamı, batı - kuzey doğu Sarnıcı, Anadolu'daki Ortodoks mimarisinin izlerini taşıyan en büyük altıgen yapılı Vaftiz hane, Urne, düz kapaklı mermer sanduka kaplı ve kiremit-tuğla örgülü mezarlar adanın önemli tarihi eserleri arasında yer alir.

İskeletin dış çevre ile doğrudan temasının bir parçası olan dişler, birçok kara memelisi ve insanın da içinde bulunduğu canlı gruplarının çevreye uyumu ve yaşam tarzı hakkında önemli bilgiler sunar. Dişler sert ve dayanıklı yapıları sebebiyle, ölüm sonrasında vücudun diğer kısımlarına oranla daha dirençli ve sağlam bir yapı sergiler. Ağız ve diş sağlığı üzerine yapılan araştırmalar sayesinde eski çağlarda yaşamış insanların beslenme şekilleri, besin hazırlama teknikleri, ağız temizliği, sosyo-ekonomik düzeyleri incelenebilmekte ve günümüz toplumlarıyla karşılaştırma yapılabilmektedir. Diş ve çene hastalıklarının teşhisi, yorumu ve görülme sıklıklarının belirlenmesi özellikle eski toplumlarda biyo-kültürel uyum süreçlerinin ortaya konmasında önemli bir rol oynamaktadır (Özbek, 2000). Diş ve çene hastalıkları toplumların beslenme şekillerine, yaşam biçimlerine, sosyo-ekonomik düzeylerine, bireylerin yaş ve cinsiyetlerine göre değişiklik gösterir. Diş ve çenelerde görülen diş aşınması, diş çürügü̆, hypoplasia, diş taşı, periyodontal hastalıklar (alveol kaybı) ve ölüm öncesi diş kaybı patolojik hastalıklar arasında yer alır. Bu lezyonların oluşma sıklığı, toplumların beslenme şekli, besin türleri, besin hazırlama teknikleri, ağız ve diş temizleme alışkanlıkları gibi biyolojik ve kültürel faktörlere, yaşanılan bölgeye ve döneme göre değişmektedir.

Dişler şekil ve ölçüleri ile de yaşayan ve ölü toplumların genetik yapısını ortaya koymakta ve topluluklar arası genetik yakınlık derecesinin belirlenmesinde, evrim tarihi ve adaptasyon gibi konularda en yoğun olarak incelenen materyaller arasında yer almaktadırlar. Bu değerlendirmeye göre kullanılan dişlerden yola çıkılarak bireye ve topluluğa ilişkin morfolojik veriler elde edilmekte, topluluklar arası biyolojik ilişkilerin belirlenmesinde anlamlı sonuçlara ulaşılabilmektedir (Hillson, 1990).

Çalışmamızın amacı, Helen - Roma - Bizans ve Osmanlı dönemine ait Zeytinli ada iskeletlerinde, çene ve dişlerde iz bırakan hastalıkların tayinini yaparak, kadın - erkek bireyler ve alt - üst dişler arasında gözlenen benzerlik ve farklılığın nedenlerini araştırmak ve elde ettiğimiz sonuçları Anadolu'da aynı dönemde yaşamış olan diğer toplumlarda gözlenen diş ve çene hastalıkları ile korele ederek bu dönemin daha çok aydınlanmasını sağlamaktır. 


\section{MATERYAL ve METOT}

Araştırma materyalini, 2007-2011 yılları arasında Doç. Dr. Nurettin Öztürk başkanlığında yapılan, Zeytinli ada kazılarında çıkarılan iskeletler oluşturmaktadır. İskeletler 2011 yılında çalışılmak üzere Cumhuriyet Üniversitesi Edebiyat Fakültesi, Paleoantropoloji laboratuvarına getirilmiştir. Bu araştırma Cumhuriyet Üniversitesi Bilimsel Araştırma Projeleri Komisyonu tarafindan (CÜBAP, EDB-006, 2011) desteklenmiştir.

Zeytinli ada toplumunun 18'i kadın, 37'si erkek, 11'i bebek ve çocuk ve 60'1 cinsiyeti bilinmeyen olmak üzere toplam 126 bireye aittir. Zeytinli ada erişkinlerine ait toplam 408 diş, bebek ve çocuklara ait ise toplam 59 diş incelenmiştir.

Bebek ve çocuklarda ergenlik çağına kadar cinsiyetin güvenilir bir şekilde belirlenememesinden dolayı çalışmada sadece erişkin bireyler üzerinde cinsiyet tespiti yapılmıştır. Zeytinli ada bireylerine ait iskeletler üzerinde cinsiyet tayini Workshop of Europen Antropologist (WEA, 1980) 'in belirlediği kriterler kullanılmıştır.

Bebek ve çocuklarda yaşlandırma, dişlerin sürme zamanına göre yapılan dental yaşlandırma metodu temel alınarak yapılmış (Ubelaker, 1978; Brothwell, 1981), erişkin bireylerde ise yaş tespitinde sutural yaşlandırma ( Oliver, 1969; WEA, 1980), dental aşınma (Brothwell, 1981) yöntemleri kullanılmıştır.

Zeytinli Ada populasyonuna ait bireylerin yaş aralığı tayininde Buikstra ve Ubelaker'den (1994); diş çürügü, çürüklerin görülme yüzeyleri ve hangi dişte görüldüğü, dişler üzerindeki apse ve apse oluşum yerleri, dişlerde gelişen hypoplasia, çenelerde alveol kaybı, diş taşı oluşumu, diş aşınması yöntemin de Brotwell (1981)'den ve tüm dişlerin aşınma derecelerinin gösterilmesinde ise Bouville ve diğ.'den (1983) yararlanılmıştır.

Zeytinli ada topluluğuna ait iskelet kalıntılarının kafa ve vücut kemiklerinin birbirinden ayrı olması, birey olarak değerlendirilme yapılmasında ve bazı bireylerde vücut iskeletlerinin hiç bulunmaması yaş ve cinsiyetlerinin tespitinde sorun oluşturmuştur. Hatta bazı bireylerde yaş ve cinsiyet tayini yapılamamıştır.

\section{BULGULAR}

\section{Zeytinli Ada Toplumunun Paleodemografik Yapısı}

\subsection{Cinsiyet Dağılımı}

Çalışma materyalini oluşturan 126 bireyin paleodemografik dağılımına bakıldığında, bu bireylerden 5'inin bebek (\% 3.96), 6'sının çocuk (\% 4.74), 18'inin kadın (\% 14.28), 37'sinin erkek (\% 29.36) ve 60'ının cinsiyeti belirlenemeyen (\% 47.61) olduğu tespit edilmiştir (Tablo 1).

Tablo 1. Zeytinli ada popülasyonunun cinsiyete göre dağılımı.

\begin{tabular}{|l|c|c|c|c|}
\hline & Kadın & Erkek & Cinsiyeti Bilinmeyen & Toplam \\
\hline Fetus & & & & 0 \\
\hline Bebek & & & & 5 \\
\hline Çocuk & & & & 6 \\
\hline Adölasan & & & & 0 \\
\hline Genç erişkin & 6 & 19 & 17 & 42 \\
\hline Orta erişkin & 3 & 10 & 36 & 49 \\
\hline İleri erişkin & 8 & 5 & 0 & 13 \\
\hline Yaşı bilinmeyen & 1 & 3 & 7 & 11 \\
\hline Toplam & 18 & 37 & 59 & 126 \\
\hline
\end{tabular}




\section{Zeytinli Ada Populasyonunda Çene Ve Dişlerde Gözlenen Patolojiler}

\subsection{Erişkinlerde Gözlenen Diş Hastalıkları}

Yapılan paleopatolojik çalışma ile Zeytinli Ada popülasyonunun genel ağız ve diş sağlığı hakkında bilgi sahibi olunacaktır. Bu amaçla, Zeytinli ada topluluğuna ait 126 bireyin 408 diş üzerinde çürük, aşınma, apse, diş taşı, alveol kaybı (periyontal hastalıklar), hypoplasia ve ölüm öncesi diş kaybı hastalıkları belirlenmiştir.

\subsection{1. Çürük}

Diş çürüklerinin oluşumunda diş tacının morfolojisindeki değişim, minedeki gelişimsel bozukluklar, sistematik ve genetik hastalıklar, dişin boyutu ve biçimi, diş dokularının sertliği ve yoğunluğu, diş minesindeki minerallerin dağılımı, dişin aşınması, periodontal hastalıklar, gelişimsel bozukluklar, hamilelik, bakteri florası, tükürüğün akışkanlı̆̆ı, ağız temizliği, yenilen besinlerin niteliği, beslenme biçimi, bağışıklık sistemi, dişin sürme yaşı, hipoplazi, yaş ve cinsiyet ve davranışsal faktörler etkilidir. (Hillson, 1990; Erdal, 1996; Featherstone, 2000; Atamtürk ve Uyar, 2008). Diş çürüğü bu etkenlerin birinin veya birkaçının oluşumuyla da oluşabilmektedir.

Zeytinli ada toplumuna ait toplam 408 dişten, 20 dişte çürük gözlenmiştir. Kadın bireylere ait 57 dişin 3'de $(\% 5,26)$, erkek bireylere ait 221 dişin 13 'de $(\% 5,88)$ ve cinsiyeti bilinmeyen bireylere ait 133 dişin 4'ünde $(\% 4,9)$ diş çürüğü saptanmıştır (Tablo 2). Çürüklerin görülme yüzeyleri açısından değerlendirildiğinde, toplam 4 (\% 20) dişte occlusual çürük, 7 (\% 35) dişte interproximal çürük ve 9 (\% 45) dişte boyun çürügü gözlenmiştir (Tablo 3; Resim 2 ve 3).

Tablo 2. Zeytinli ada toplumuna ait diş patolojilerinin cinsiyete göre dağılımı.

\begin{tabular}{|l|c|c|c|c|c|c|c|c|c|c|c|c|}
\hline \multirow{2}{*}{ Patolojiler } & \multicolumn{3}{|c|}{ Kadın } & \multicolumn{4}{c|}{ Erkek } & \multicolumn{3}{c|}{ Bilinmeyen } & \multicolumn{3}{c|}{ Toplam } \\
\cline { 2 - 13 } & B & G & \% & B & G & \% & B & G & \% & B & G & \% \\
\hline Cürük & 57 & 3 & 5,26 & 221 & 13 & 5,88 & 130 & 4 & 4,9 & 408 & 20 & 4,9 \\
\hline Apse & 57 & 1 & 1,75 & 221 & 20 & 9,09 & 130 & 6 & 4,61 & 408 & 27 & 6,61 \\
\hline Diş Taş1 & 57 & 42 & 73,68 & 221 & 144 & 65,15 & 130 & 104 & 80 & 408 & 290 & 71,07 \\
\hline Alveol Kayb1 & 57 & 43 & 75,43 & 221 & 209 & 94,57 & 130 & 113 & 86,92 & 408 & 365 & 89,46 \\
\hline Hypoplasia & 57 & 24 & 42,1 & 221 & 103 & 46,6 & 130 & 47 & 36,15 & 408 & 174 & 42,64 \\
\hline $\begin{array}{l}\text { Antemortem (Birey } \\
\text { Saysina Göre) }\end{array}$ & 21 & 16 & 76,19 & 41 & 18 & 43,90 & 27 & 6 & 22,22 & 89 & 40 & 44,94 \\
\hline
\end{tabular}

Tablo 3. Diş çürüğ̈nün yüzeylere ve cinsiyete göre dağılımı.

\begin{tabular}{|l|c|c|c|}
\hline \multicolumn{1}{|c|}{$\begin{array}{c}\text { Cürrük } \\
\text { yüzeyleri }\end{array}$} & Kadın & Erkek & Cins. Bilinmeyen \\
\hline Occlusual çürük & 0 & 3 & 1 \\
\hline İnterproximal çürük & 2 & 4 & 1 \\
\hline Boyun çürüğ̈̈ & 1 & 6 & 2 \\
\hline Toplam & 3 & 13 & 4 \\
\hline
\end{tabular}

Zeytinli ada ile diğer Anadolu toplumları diş çürüğü açısından karşılaştırıldığında; çürük oranının en yüksek olduğu 19. yy dönemine ait Kelenderis (\%28,42; Şimşek ve diğ., 2008) ve en düşük olduğu ise Urartu dönemine ait Altıntepe (\%2,85; Yiğit ve diğ., 2005) toplumlarıdır (Tablo 4). 


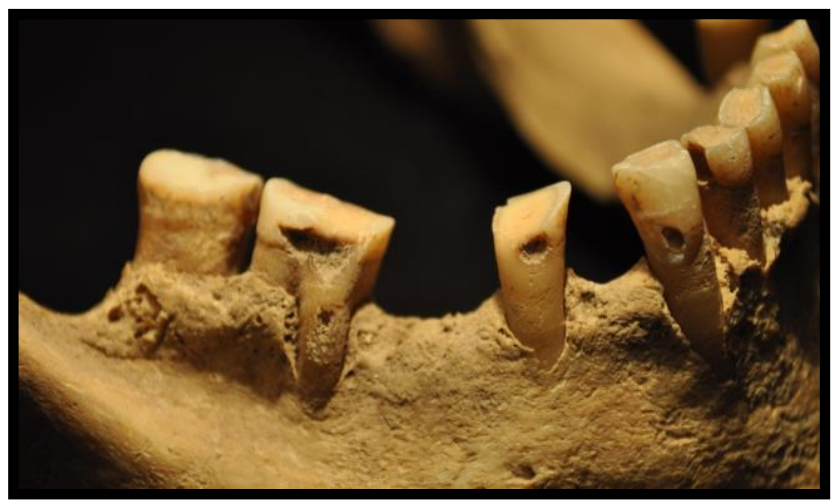

Resim 2. ZK-18 no'lu bireye ait alt çenede diş çürüğü.

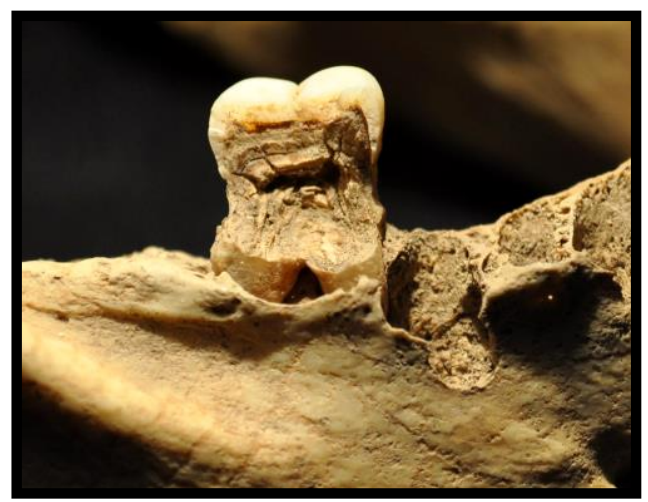

Resim 3. ZK-35 no'lu bireye ait alt çenede diş çürüğ̈̈.

Tablo 4. Zeytinli ada toplumunda erişkin bireylerin çene ve diş patolojileri açısından diğer Anadolu toplumlarıyla karşılaştırılması.

\begin{tabular}{|c|c|c|c|c|c|c|c|c|c|}
\hline Topluluk & Dönem & $\begin{array}{c}\text { Araştırı } \\
\text { cl }\end{array}$ & $\begin{array}{c}\text { Diş } \\
\text { Çürüğ } \\
\underset{\text { ü }}{(\%)}\end{array}$ & $\begin{array}{c}\text { Diş } \\
\text { Așınma } \\
\text { sı } \\
\text { (Așınma } \\
\text { Derecesi } \\
\text { ) }\end{array}$ & $\begin{array}{c}\text { Aps } \\
\text { e } \\
(\%)\end{array}$ & $\begin{array}{c}\text { Hypoplasi } \\
\text { a } \\
(\%)\end{array}$ & $\begin{array}{l}\text { Diş } \\
\text { Taşı } \\
(\%)\end{array}$ & $\begin{array}{c}\text { Diş Kaybı } \\
\text { (Antemorte } \\
\text { m) } \\
(\%)\end{array}$ & $\begin{array}{c}\text { Periodont } \\
\text { al } \\
\text { Hastalıkla } \\
\text { r }\end{array}$ \\
\hline AşıklıHöyük & Neolitik & $\begin{array}{l}\text { Özbek } \\
(1998)\end{array}$ & 2,9 & - & 26,3 & 3,7 & 9,5 & 7,6 & 29,4 \\
\hline Çayönü & Neolitik & $\begin{array}{l}\text { Özbek } \\
\text { (1997) }\end{array}$ & 4,3 & 5 & 20,2 & 2,8 & 64 & 27,8 & 36,6 \\
\hline Küçükhöyük & $\begin{array}{l}\text { Erken } \\
\text { Tunç }\end{array}$ & $\begin{array}{c}\text { Açıkkol } \\
(2000)\end{array}$ & 2,92 & 4 & - & 13,79 & 1,58 & - & 57,9 \\
\hline Hayazhöyük & $\begin{array}{l}\text { Erken } \\
\text { Tunç }\end{array}$ & $\begin{array}{l}\text { Özbek } \\
\text { (1984) }\end{array}$ & 3,93 & 1 ve 2 & - & - & - & - & - \\
\hline Karataş & $\begin{array}{c}\text { Erken } \\
\text { tunç }\end{array}$ & $\begin{array}{l}\text { Angel } \\
(1970)\end{array}$ & 5,6 & - & 0,72 & 6,0 & - & 3,56 & 5,02 \\
\hline Resuloğlu & $\begin{array}{l}\text { Erken } \\
\text { Tunç }\end{array}$ & $\begin{array}{l}\text { Atamtür } \\
\text { k ve } \\
\text { Duyar } \\
(2010)\end{array}$ & 3,74 & - & 2,34 & 57,23 & $\begin{array}{c}79,7 \\
7\end{array}$ & 3,22 & 97,31 \\
\hline $\begin{array}{l}\text { AkhanMezarlı } \\
\text { ğg }\end{array}$ & Tunç & $\begin{array}{l}\text { Günay, } \\
\text { (2007) }\end{array}$ & - & 3 ve 4 & - & - & - & - & - \\
\hline Ağızören & $\begin{array}{l}\text { Orta } \\
\text { Tunç }\end{array}$ & $\begin{array}{l}\text { Yilmaz } \\
\text { ve diğg., } \\
(2003)\end{array}$ & - & 4 & 25 & 27,4 & 17,7 & 7,6 & - \\
\hline Panaztepe & 2.bin & $\begin{array}{c}\text { Güleç ve } \\
\text { Duyar } \\
\text { (1998) }\end{array}$ & 3,01 & - & - & 31,51 & - & 15,65 & - \\
\hline Hakkari & $\begin{array}{l}\text { Erken } \\
\text { Demir }\end{array}$ & $\begin{array}{l}\text { Gözlük } \\
\text { ve diğ. } \\
(2003)\end{array}$ & 5,56 & 4 & 3,56 & 20,15 & $\begin{array}{c}20,1 \\
5\end{array}$ & 19,79 & 60,98 \\
\hline
\end{tabular}


Zeytinli Ada İskelet Topluluğunun Diş ve Çene Patolojisi Açısından İncelenmesi

\begin{tabular}{|c|c|c|c|c|c|c|c|c|c|}
\hline Karagündüz & $\begin{array}{l}\text { Erken } \\
\text { Demir }\end{array}$ & $\begin{array}{l}\text { Erkman } \\
\text { ve diğ. } \\
(2008)\end{array}$ & - & - & 2,58 & 2,8 & $\begin{array}{c}15,1 \\
8\end{array}$ & 9,17 & - \\
\hline Norşuntepe & Demir & $\begin{array}{c}\text { Korkmaz } \\
\text { (1993) }\end{array}$ & 11,27 & - & $\begin{array}{c}26,6 \\
6\end{array}$ & 87,5 & 66,6 & 13,8 & 90 \\
\hline Altıntepe & Urartu & $\begin{array}{l}\text { Yiğit ve } \\
\text { diğ. } \\
(2005)\end{array}$ & 2,85 & - & 3,90 & 9,28 & $\begin{array}{c}11,2 \\
6\end{array}$ & 7,89 & 12,70 \\
\hline Dilkaya & $\begin{array}{c}\text { М.Ö.7- } \\
\text { 6.уy. }\end{array}$ & $\begin{array}{c}\text { Güleç } \\
\text { (1987) }\end{array}$ & 10 & - & - & - & - & - & - \\
\hline $\begin{array}{l}\text { Klaz- } \\
\text { Yıldıztepe }\end{array}$ & $\begin{array}{c}\text { M.Ö.6- } \\
\text { 5.yy. }\end{array}$ & $\begin{array}{l}\text { Güleç } \\
\text { (1986) }\end{array}$ & 5,2 & 3 ve 4 & - & - & - & 3,7 & - \\
\hline Klaz-Akpınar & $\begin{array}{c}\text { M.Ö.7- } \\
\text { 4.уy. }\end{array}$ & $\begin{array}{c}\text { Güleç ve } \\
\text { diğg. } \\
(1998)\end{array}$ & 5,4 & 4 & - & 35 & 12,5 & 3,4 & - \\
\hline Antandros & $\begin{array}{c}\text { М.Ö.7- } \\
\text { 2.уy. }\end{array}$ & $\begin{array}{c}\text { Erdal } \\
(2001)\end{array}$ & 9,8 & 4 & 5,4 & 60,3 & - & 17,5 & - \\
\hline Panaztepe & Roma & $\begin{array}{c}\text { Güleç ve } \\
\text { Duyar } \\
\text { (1998) }\end{array}$ & 11,11 & - & - & 22,73 & $\begin{array}{c}14,7 \\
6\end{array}$ & 11,11 & - \\
\hline Datça & Roma & $\begin{array}{l}\text { Sevim } \\
\text { (1996) }\end{array}$ & 16 & - & - & - & - & 21,3 & - \\
\hline Arslantepe & $\begin{array}{c}\text { Geç } \\
\text { Roma }\end{array}$ & $\begin{array}{c}\text { Uzel ve } \\
\text { diğ. } \\
\text { (1988) }\end{array}$ & 9,52 & 1 ve 2 & - & - & 80 & 14,2 & - \\
\hline Sardis & $\begin{array}{l}\text { G.Roma } \\
\text { ve } \\
\text { E.Bizans }\end{array}$ & $\begin{array}{l}\text { Eroğlu } \\
\text { (1998) }\end{array}$ & 8.7 & - & 7,26 & 64,54 & $\begin{array}{c}56,5 \\
2\end{array}$ & 16,04 & 82,31 \\
\hline Kyzikos & $\begin{array}{c}\text { M.S.2.y } \\
\text { Y }\end{array}$ & $\begin{array}{l}\text { Gözlük } \\
\text { ve diğ. } \\
\text { (2008) }\end{array}$ & 7,76 & - & 0 & 56,73 & 5,31 & 3,79 & 100 \\
\hline Adramytteion & $\begin{array}{c}\text { M.S.5- } \\
6 y y\end{array}$ & $\begin{array}{c}\text { Erdal } \\
(2001)\end{array}$ & 10,10 & - & 1,36 & 60,23 & $\begin{array}{c}29,6 \\
1\end{array}$ & 9,43 & 80,00 \\
\hline $\begin{array}{l}\text { Smyrna } \\
\text { Agorası }\end{array}$ & Bizans & $\begin{array}{l}\text { Gözlük } \\
\text { ve diğ. } \\
\text { (2005) }\end{array}$ & 4,68 & - & 1,63 & 11,7 & $\begin{array}{c}16,9 \\
6\end{array}$ & 7,61 & 33,33 \\
\hline İznik & $\begin{array}{c}\text { Geç } \\
\text { Bizans }\end{array}$ & $\begin{array}{c}\text { Erdal } \\
(1996)\end{array}$ & 10,88 & - & 3,93 & 36,80 & $\begin{array}{c}59,2 \\
8 \\
\end{array}$ & 7 & 70,83 \\
\hline Eski Cezaevi & $\begin{array}{c}\text { G. } \\
\text { Bizans }\end{array}$ & $\begin{array}{c}\text { Erdal } \\
(2003)\end{array}$ & 9,6 & - & 5,1 & 75,4 & 57,2 & 12 & 33,1 \\
\hline Tlos & Bizans & $\begin{array}{l}\text { Atamtür } \\
\text { k ve diğ. } \\
(2011)\end{array}$ & 8,9 & - & 1,1 & 37,6 & 21,9 & - & 68 \\
\hline Alanya Kalesi & Bizans & $\begin{array}{c}\text { Üstünda } \\
\text { ğ ve } \\
\text { Demirel, } \\
(2009)\end{array}$ & 12,6 & - & 2,3 & 39,7 & - & - & 35,3 \\
\hline Karagündüz & $\begin{array}{l}\text { Orta } \\
\text { Çağ }\end{array}$ & $\begin{array}{l}\text { Gözlük } \\
\text { (2004) }\end{array}$ & 6,36 & 4 & 1,86 & 24,91 & 25,9 & 18,73 & 40,64 \\
\hline Van Kalesi & $\begin{array}{l}\text { Orta } \\
\text { Çağ }\end{array}$ & $\begin{array}{l}\text { Gözlük } \\
\text { ve diğ. } \\
(2004)\end{array}$ & 11,75 & 4 & 1,72 & 30,42 & 47 & 18,28 & 39,74 \\
\hline Minnetpınarı & $\begin{array}{l}\text { Orta } \\
\text { Çağ }\end{array}$ & $\begin{array}{c}\text { Yaşar } \\
(2007)\end{array}$ & 7,6 & 4 ve 5 & - & 21 & 15,6 & 49,3 & 75,5 \\
\hline Güllüdere & $\begin{array}{l}\text { Orta } \\
\text { Çağ }\end{array}$ & $\begin{array}{c}\text { Yaşar } \\
(2007)\end{array}$ & 3,6 & 4 ve 5 & - & 11,9 & 10,2 & 50,2 & 80 \\
\hline Panaztepe & İslam & $\begin{array}{c}\text { Güleç } \\
\text { (1989) }\end{array}$ & 7,3 & 3 & - & 5,7 & - & - & - \\
\hline Kelenderis & 19.yy & $\begin{array}{l}\text { Şimşek } \\
\text { ve diğ. } \\
\text { (2008) }\end{array}$ & 28,42 & 3 & 2,21 & 51,01 & $\begin{array}{c}58,8 \\
8\end{array}$ & 34,24 & 100 \\
\hline Zeytinliada & $\begin{array}{l}\text { Helen- } \\
\text { Roma } \\
\text { Bizans- } \\
\text { Osmanlı }\end{array}$ & & 4,9 & 4 & 6,61 & 42,64 & $\begin{array}{c}71,0 \\
7\end{array}$ & 38,27 & 58,42 \\
\hline
\end{tabular}




\subsubsection{Aşınma}

Aşınma, besinlerin çiğnenmesi sırasında fiziksel ve fizyolojik etkilerin sert diş minesi üzerinde oluşturduğu yıkımdır (Özbek, 2007).

Zeytinli ada bireylerinin dişlerinde gözlenen aşınma yoğun olarak 4 derecesindedir. Zeytinli ada bireyleri cinsiyete göre diş aşınması bakımından değerlendirildiğinde, erkek bireylerde en sık rastlanan aşınma derecesi 4, kadın bireylerde daha ileri seviye olan 4+ derecesindedir. Zeytinli ada toplumunda erkek bireylerde aşınma oranı \% 54,16 ve kadın bireylerde ise \%13,97'dir. Cinsiyeti bilinmeyen bireylerde ise bu oran \% 31,86'dır (Tablo 5; Resim 4).

Tablo 5. Zeytinli ada toplumunda sürekli dişlerin aşınma durumları.

\begin{tabular}{|c|c|c|}
\hline Derece & Diş Sayısı & $\%$ \\
\hline 1 & 15 & 3.67 \\
\hline 2 & 39 & 9.55 \\
\hline $2+$ & 19 & 4.65 \\
\hline $3-$ & 12 & 2.94 \\
\hline 3 & 53 & 12.99 \\
\hline $3+$ & 54 & 13.23 \\
\hline 4 & 88 & 21.56 \\
\hline $4+$ & 60 & 14.70 \\
\hline 5 & 46 & 11.27 \\
\hline $5+$ & 12 & 2.94 \\
\hline $5++$ & 1 & 0.24 \\
\hline 6 & 2 & 0.49 \\
\hline 7 & 7 & 1.71 \\
\hline Toplam & 408 & 100 \\
\hline
\end{tabular}

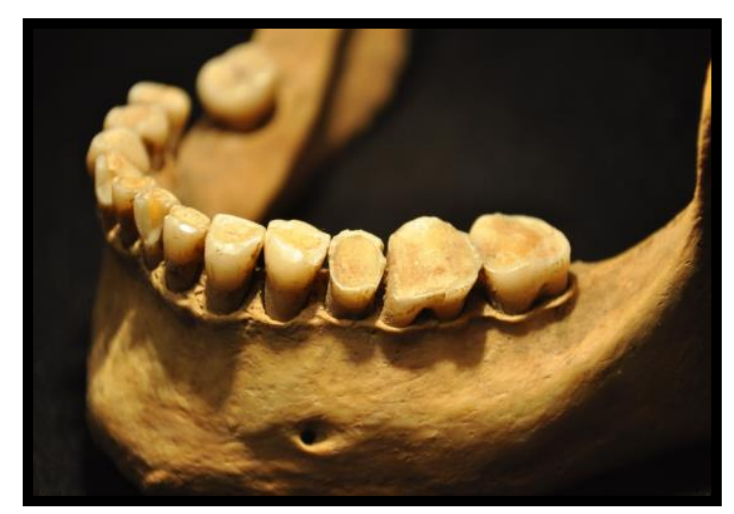

Resim 4. ZK-7 no'lu bireye ait alt çenede diş aşınması.

Zeytinli ada ile çağdaşı olan diğer Anadolu toplumları diş aşınma dereceleri açısından korele edildiğinde büyük bir benzerlik gösterdiği tespit edilmiştir (Tablo 4).

\subsubsection{Apse}

Apse, ileri derecedeki çürük ve aşınmalar, diş özü odacığının dışa açılması, periyodontal hastalıklar ve travmatik faktörler sonucunda oluşan bir lezyon olarak tanımlanabilir. Zeytinli ada erişkinlerine ait 408 dişin 27 'sinde (\% 6,61), bunlardan üst çeneye ait 218 dişin 23 'ünde (\% 10,55) ve alt çeneye ait 190 dişin 4'ünde (\% 2,10) apse gözlenmiştir (Tablo 2; Resim 5).

Apse eski Anadolu toplumlarını farklı oranlarda etkilemiştir. Apse oranı en fazla Demir dönemi Norşuntepe (\% 26,66; Korkmaz, 1993) ve en az M.S. 2.yy dönemine ait Kyzikos (\% 0; 


\section{Zeytinli Ada İskelet Topluluğunun Diş ve Çene Patolojisi Açısından İncelenmesi}

Gözlük ve diğ., 2008) toplumlarında görülmektedir. Zeytinli ada $(\%$ 6,61) apse bakımından çağdaşı olan diğer eski Anadolu toplumları ile büyük bir benzerlik sergilemektedir (Tablo 4).

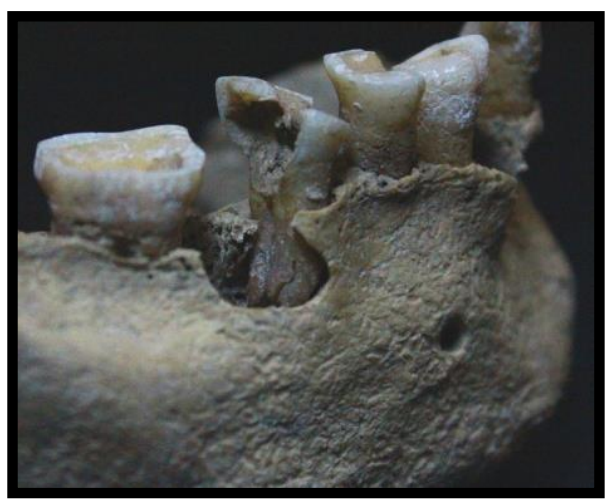

Resim 5. ZK-20 no'lu bireye ait alt çenede apse.

\subsubsection{Diş Taşı}

Diş taşı, dişlerin mine yüzeylerinde özellikle diş eti sınırında biriken plağın mineralleşmesi sonucunda ortaya çıkan inorganik bir yapıdır (Ortner ve Putschar,1985). Zeytinli ada popülasyonuna ait 408 dişten 290'ında (\% 71,07) diş taşına rastlanılmıştır (Tablo 2).

Zeytinli ada kadın bireylerine ait 57 dişin 42 'sinde $(\% 73,68)$ yani üst çenede 18 dişin 11 'inde $(\%$ 61,11) ve alt çenede 39 dişin 31 'inde $(\%$ 76,68) diş taş1 oluşumu tespit edilmiştir (Resim, 6). Kadın bireylerde üst çenede diş taşı $\mathrm{C}, \mathrm{P}^{1}$ ve $\mathrm{P}^{2}$, alt çenede $\mathrm{M}_{1}$ dişlerde daha fazla görülmektedir. Zeytinli ada toplumunda erkek bireylere ait 221 dişin 144'ünde $(\% 65,15)$ yani üst çenede 104 dişin 83'ünde $(\% 79,8)$ ve alt çenede 117 dişin 61'inde $(\%$ 52,13) diş taş1 oluşumuna rastlanılmaktadır. Bu bireylerde üst çenede diş taşının en yoğun olduğu diş $\mathrm{M}^{1}$, alt çenede $\mathrm{P}_{1}$ ve $\mathrm{M}_{1}$ 'dir.

Eski Anadolu toplumları arasında, diş taşı oranı Geç Roma dönemi Arslantepe (\% 80; Uzel ve diğ., 1988) toplumunda en yüksek, Erken Tunç dönemi Küçükhöyük (\% 1,58; Açıkkol 2000) toplumunda ise en düşüktür. Zeytinli ada toplumunda diş taşı görülme oranı $(\% 71,07)$ Resuloğlu (\% 79,77; Atamtürk ve Duyar 2010) ve Arslantepe (\% 80; Uzel ve diğ., 1988) toplumları hariç, diğerlerine göre oldukça yüksektir (Tablo 4).

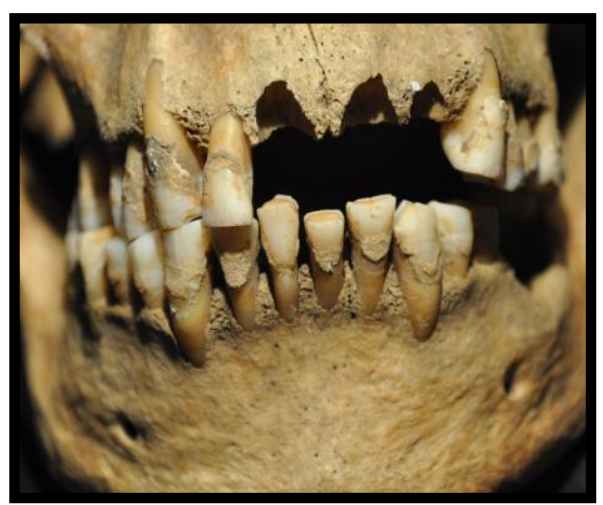

Resim 6. ZK-31 no'lu bireye ait alt ve üst çenede diş taş1. 


\subsubsection{Alveol Kaybı (Periyodontal hastalıklar)}

Periyontal rahatsızlık temiz tutulmayan ağız, aşınma, diş taşı, çürük, apse gibi lezyonlar sonucunda mikroorganizmaların etkisiyle dişi çevreleyen diş eti dokusunun iltihaplanması nedeniyle diş eti ve alveol kemik dokularının çekilmesi/kaybı olarak tanımlanmaktadır (Erdal, 1996). Zeytinli ada bireylerine ait 408 dişin 365 'inde (\% 89,46) alveol kaybına rastlanmıştır. Kadın bireylerde üst çenede 15 (\% 83,3) ve alt çenede 28 dişte(\% 75,43), erkek bireylerde ise üst çenede $98(\%$ 94,2) ve alt çenede 111 dişte $(\%$ 94,57) alveol kaybı tespit edilmiştir (Tablo 2; Resim 7).

Zeytinli ada ile Eski Anadolu toplumları alveol kaybı açısından karşılaştırıldığında, alveol kaybının en düşük gözlendiği toplum Karataş (\% 5,02; Angel, 1970), en yüksek ise Kelenderis (\%100; Şimşek ve diğ 2008) ve Kyzikos (\%100; Gözlük ve diğ., 2008) olarak göze çarpmaktadır. Zeytinli ada toplumunda bu oran \%58,42 olarak hesaplanmıştır (Tablo 4).

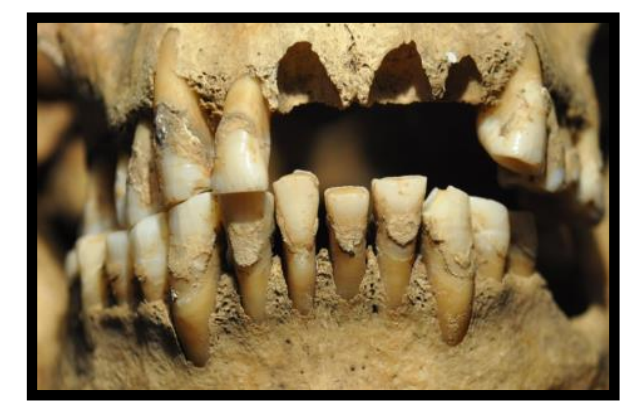

Resim 7. ZK-31 no'lu bireyde alveol kayb1.

\subsubsection{Hypoplasia}

Diş minesinin oluşum sürecinde (amelogenesis) fizyolojik streslere bağlı olarak ameloblastların aktivitesinde meydana gelen aksama nedeniyle, mine kalınlığında ortaya çıkan eksiklik olarak tanımlanmaktadır. Mine defektlerine neden olabilecek birçok etmen bulunmaktadır. Beslenme yetersizliği, anne sütünü emme süresi, prematüre doğum, nörolojik rahatsılıklar, acidosis, kalsiyum fosfat dağılımı, florisis sendromu gibi genetik rahatsılılklar, bakteriyel enfeksiyonlar, kızıl, kızamık, grip ve suçiçeği gibi viral enfeksiyonlar bu etmenler arasinda sayılabilir (Erdal, 1996).

Zeytinli ada topluluğuna ait 408 dişten 174 'ünde $(\%$ 42,64) hypoplasia, az / hafif $(\% 71,26)$, orta $(\% 28,16)$ ve ileri $(\% 2,87)$ derecede görülmüştür (Tablo 2). Zeytinli ada populasyonunda kadın bireylerde 57 dişin 24'ünde (\% 42,1) üst çenede $\% 38,88$, alt çenede $\% 43,58$ ve erkek bireylerde 221 dişin 103 'ünde ( $\% 46,6)$, üst çenede $\% 40,38$ ve alt çenede ise $\% 52,13$ oranında hypoplasia'ya rastlanmıştır (Resim, 8).

Zeytinli ada topluluğunda hypoplasia s1klığ $\%$ 42,64 olarak tespit edilmiştir. Zeytinli ada ile Eski Anadolu toplumları hypoplasia açısından karşılaştırıldığında, hypoplasianın en düşük gözlendiği toplum Çayönü (\% 2,8; Özbek, 1997) ve Karagündüz (\% 2,8; Erkman ve diğ., 2008), en yüksek ise Norşuntepe (\%87,5; Korkmaz,1993)'dir (Tablo 4). 


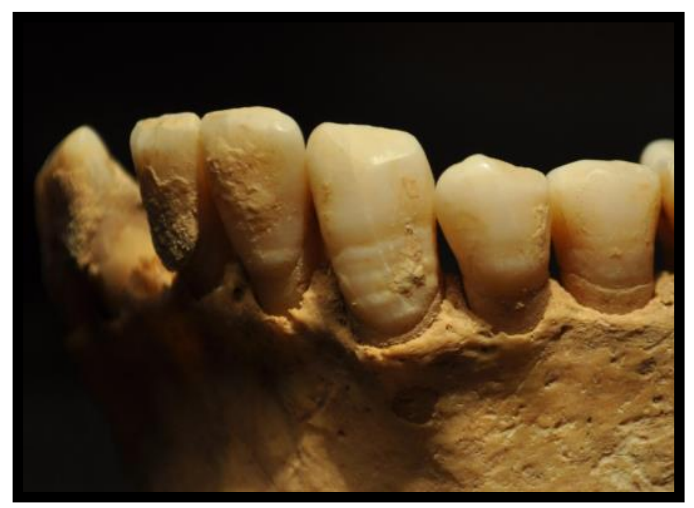

Resim 8. ZK-2 no'lu bireye ait alt çenede hypoplasia.

\subsection{7. Ölüm Öncesi (Antemortem )Diş Kaybı}

Ölüm öncesi diş kaybı ilerlemiş çürük, periyodontal hastalıklar, diş taşı birikimi ve belirgin aşınmalar sonucunda ortaya çıkmaktadır. Aşınmanın fazla olması pulpa boşluğunun ortaya çıkmasına neden olur ve bu durum diş kaybına neden olur. Diş taşının birikmesi sonucunda alveolar kemiğin çekilmesi sonucu dişler kaybedilir. Zeytinli ada toplumunda ölüm öncesi diş kaybı en fazla M1 (\% 21,15) dişinde en az ise I2 (\% 5,49)' de görülmektedir (Tablo 6; Resim 9 ve 10).

Tablo 6. Zeytinli ada toplumunda dişlere göre ölüm öncesi diş kaybı dağılımı.

\begin{tabular}{|l|c|c|}
\hline DișLER & $\begin{array}{c}\text { ÖLÜM ÖNCESI } \\
\text { Dis KAYBI }\end{array}$ & $\%$ \\
\hline M3 & 37 & 14,50 \\
\hline M2 & 44 & 17,25 \\
\hline M1 & 55 & 21,56 \\
\hline P2 & 38 & 14,9 \\
\hline P1 & 31 & 12,15 \\
\hline C & 17 & 6,66 \\
\hline I2 & 14 & 5,49 \\
\hline I1 & 17 & 6,66 \\
\hline Toplam & 253 & 100 \\
\hline
\end{tabular}

Birey sayısına göre, 21 kadın bireyin 16 (76,19)'sında, 41 erkek bireyin 18 (43,90)'inde, 27 cinsiyeti bilinmeyen bireyin 6 (22,22)'sında ölüm öncesi diş kaybı görülmektedir. Toplum geneline bakıldığında 89 bireyin $40(44,94)$ 'ında bu lezyona rastlanılmaktadır (Tablo 7).

Tablo 7. Zeytinli ada toplumunda birey sayısına göre ölüm öncesi diş kaybı sıklığı.

\begin{tabular}{|ccccccccccccc|}
\hline & \multicolumn{3}{c}{ KADIN } & \multicolumn{3}{c}{ ERKEK } & \multicolumn{2}{c|}{ C.BIILINMEYEN } & \multicolumn{3}{c|}{ GENEL } \\
\hline \multirow{\text{ÜST}}{*}{ ÇENE } & $\mathrm{B}$ & $\mathrm{G}$ & $\%$ & $\mathrm{~B}$ & $\mathrm{G}$ & $\%$ & $\mathrm{~B}$ & $\mathrm{G}$ & $\%$ & $\mathrm{~B}$ & $\mathrm{G}$ & $\%$ \\
\cline { 2 - 14 } & 11 & 8 & 72,72 & 22 & 9 & 40,90 & 21 & 6 & 28,57 & 54 & 23 & 42,59 \\
\hline ALT & $\mathrm{B}$ & $\mathrm{G}$ & $\%$ & $\mathrm{~B}$ & $\mathrm{G}$ & $\%$ & $\mathrm{~B}$ & $\mathrm{G}$ & $\%$ & $\mathrm{~B}$ & $\mathrm{G}$ & $\%$ \\
\cline { 2 - 13 } ÇENE & 10 & 8 & 80 & 19 & 9 & 47,36 & 6 & 0 & 0 & 35 & 17 & 48,57 \\
\hline TOPLAM & 21 & 16 & 76,19 & 41 & 18 & 43,90 & 27 & 6 & 22,22 & 89 & 40 & 44,94 \\
\hline
\end{tabular}


Eski Anadolu toplumları arasında ölüm öncesi diş kaybı diş sayısına göre karşılaştırıldığında; en yüksek Orta Çağ dönemi Güllüdere (\% 50,2; Yaşar, 2007) ve en düşük orana sahip Erken Tunç dönemi Resuloğlu (\% 3,22; Atamtürk ve Duyar, 2010) toplumudur (Tablo 4). Zeytinli ada toplumunda ise bu oran $\% 38,27$ 'dir.

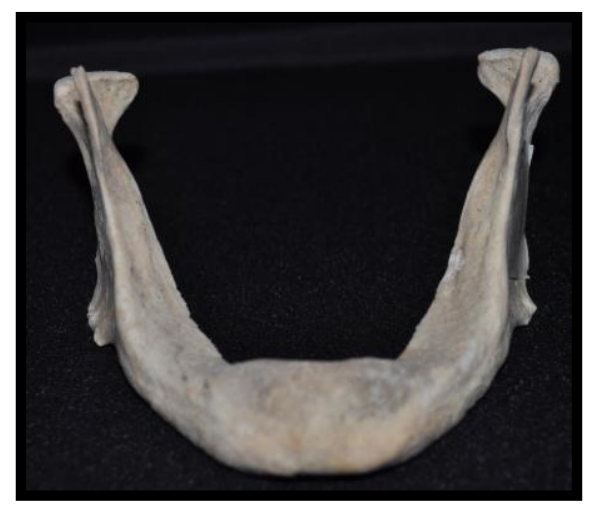

Resim 9. ZK-8 no'lu bireyde antemortem diş kaybı.

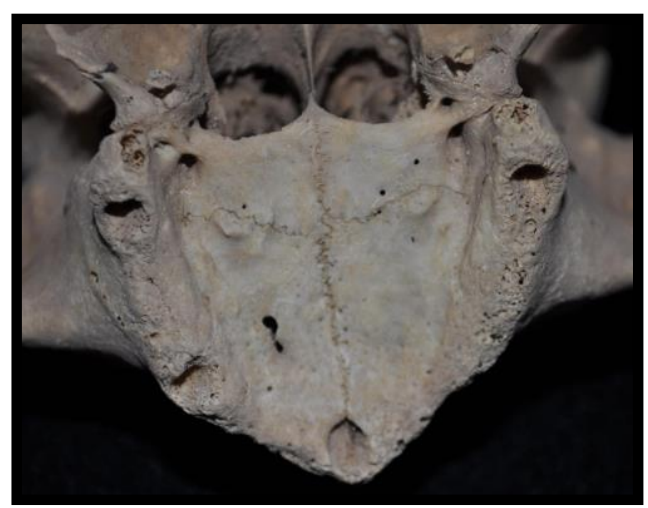

Resim 10. ZK-8 no'lu bireye ait üst çenede antemortem diş kaybı.

\subsubsection{Odontoma}

Odontoma; mine, dentin, sement ve bağ dokusu yapılarını içeren, doku değişimine uğramış odontojenik tümör olarak tanımlanmaktadır. Mandibulada, premolar- molar bölgede sıkça görülen diş tümörüdür. Bu yapıyı gösteren dişlerde bütün dental dokular vardır fakat bunlar kötü organizedir ve düzensizdir (Küçükkolbaşı ve Kızıloğlu, 2007). Odontoma etilojisi tam olarak bilinmemektedir. Dişlerin sürmesindeki bozukluklar, travma, enfeksiyon ve genetik kontrol mekanizmalarında bozulmalar sonucu oluştuğu öne sürülmektedir. Odontomaların sürekli büyüme olasılıkları vardır. Odontomolar genel olarak yaşamın birinci veya ikinci on yılında oluşmaktadır (Küçükkolbaşı ve Kızıloğlu, 2007).

Zeytinli ada toplumunda incelenen bir alt çenin sol tarafında odontoma gözlenmiştir. Sol mandibula parçasında, birinci büyük azı ve ikinci büyük azı dişlerinin çene içerinde taç kısımlarının kaynaşması sonucunda odontoma diye tanımlanan odontojen çene ve diş tümörü saptanmıştır. Çenede şişlik oluşturan bu oluşum röntgenlenerek incelenmiş ve diş hekimlerinin de incelemeleri sonucunda odontoma olduğu tespit edilmiştir (Resim 11). 


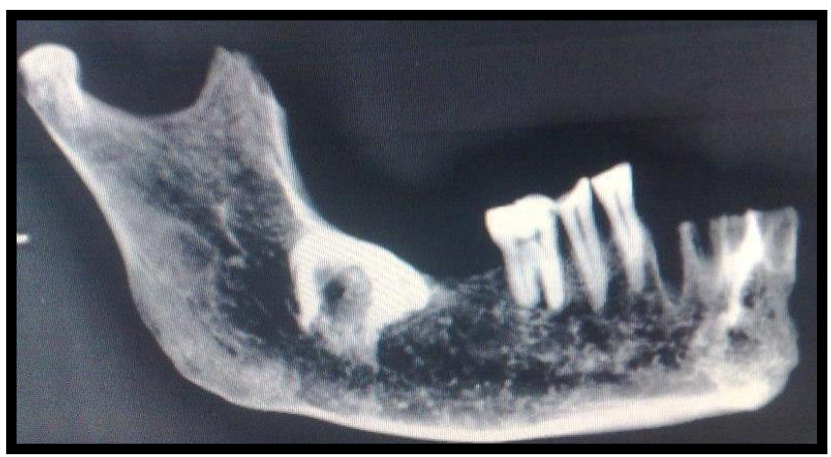

Resim 11. Zeytinli ada bireyine ait mandibula parçasında odontoma görünümü.

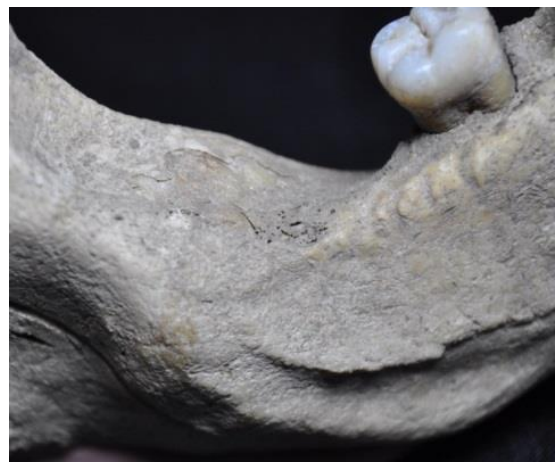

a

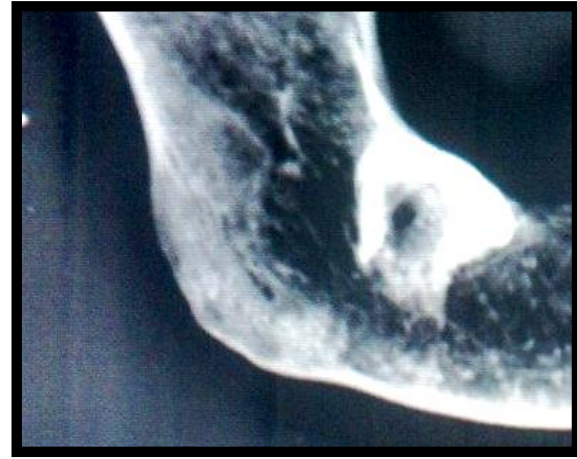

b

Resim 12 a ve b. Zeytinli ada bireyine ait mandibula parçasında odontoma görünümü.

\subsection{BEBEK VE ÇOCUKLARDA DİŞ VE ÇENE PATOLOJILERİ}

\subsubsection{Bebek ve Çocuklarda Görülen Diş ve Çene Hastalıkları}

Zeytinli ada popülasyonunda 5'i bebek ve 6'si çocuğa ait, 27'si süt ve 32'si daimi diş olmak üzere toplam 59 diş bulunmaktadır. Bu toplumda toplam 11 bireyin diş ve çeneleri incelenmiştir. Dişler üzerinde çürük, aşınma, apse, diş taşı, alveol kaybı, hypoplasia ve ölüm öncesi diş kaybı oluşumları bakılmıştır. Karışık dişlenmeye sahip Zeytinli ada çocuk bireylerde daimi diş ve süt dişi ayrı ayrı incelenmiştir.

\subsubsection{1. Çürük}

Zeytinli ada toplumu bebek ve çocuklara ait 59 diş üzerinde çürüğe rastlanılmamıştır (Tablo $8)$.

\subsubsection{Hypoplasia}

Zeytinli ada toplumu bebek ve çocuklara ait 27 süt dişinde hypoplasia oluşumu rastlanmamış ve 32 daimi dişin 8'inde (\%25) ise hypoplasia görülmüştür (Tablo 8).

\subsubsection{Diş Taşı}

Bebek ve çocuklara ait toplam 59 dişin $35^{\prime}$ inde $(\% 59,32)$ diş taşının varlığı saptanmıştır (Tablo 7). Bu dişlerden, 27 süt dişinin 13 'ünde ( $\% 48)$ ve 32 daimi dişin 22 'sinde ( $\%$ 68) az derecede diş taşı oluşumu mevcuttur. 


\subsubsection{Diş Aşınması}

Zeytinli ada toplumu bebek ve çocuklarda 59 dişin 32'sinde $(\% 54,24)$ diş aşınması görülmüştür ve bu dişlerin aşınma derecesi ortalaması 1,02'dir (Tablo 7). Daimi dişlerde üst çeneye ait 23 ve alt çeneye ait 9 diş incelenmiştir. Üst çenede 23 dişin 13 'ünde $(\% 40,6) 1$ düzeyinde, 3 'ünde $(\% 9,37) 2$ düzeyinde, l'inde $(\% 3,12) 3$ düzeyinde, 4'ünde $(\% 12,5) 3$ düzeyinde, 2 'sinde $(\% 6,25) 4$ düzeyinde diş aşınması gözlenmiştir. Alt çenede ise 9 dişin 4 'ünde (\% 12,5) 1 düzeyinde, 3'ünde (\% 9,37) 3 düzeyinde, 2'sinde $(\% \quad 6,25) 4$ düzeyinde aşınma görülmüştür. Alt çenede aşınma oranı \% 28,1, üst çenede ise $\% 71,8^{\circ}$ dir.

\begin{tabular}{|c|c|c|c|}
\hline Patolojiler & B & G & $\%$ \\
\hline Çürük & 59 & 0 & 0 \\
\hline Hypoplasia & 59 & 8 & 13,56 \\
\hline Diş Taş1 & 59 & 35 & 59,32 \\
\hline Diş Aşınması & 59 & 32 & $\begin{array}{c}54,24 \\
\text { (Aşınma Derecesi } \\
\text { Ortalaması:1,02) }\end{array}$ \\
\hline
\end{tabular}

Tablo 8. Zeytinli ada toplumuna ait bebek ve çocuklarda görülen patolojiler.

\section{SONUÇ}

Helen-Roma-Bizans-Osmanlı dönemi ile tarihlendirilen Zeytinli ada topluluğuna ait, 18'i kadın, 37'si erkek, 60'cinsiyeti bilinmeyen, 5'i bebek ve 6'sı çocuk olmak üzere toplam 126 birey incelenmiştir. 408'i erişkin bireylere, 59'u bebek ve çocuklara ait toplam 467 diş üzerinde çürük, aşınma, apse, diş taşı, alveol kaybı (periyontal hastalıklar), hypoplasia ve ölüm öncesi diş kaybı hastalıklarına bakılmış ve bunların taraflara ve cinsiyetlere göre dağılımı tespit edilmiştir.

Zeytinli ada iskelet topluluğunda incelenen 408 dişte, diş çürüğü \% 4,90; apse \% 6,61; diş taş1 $\%$ 71,07; alveol kayb1 \% 89,46; hypoplasia \% 42,64 ve antemortem diş kayb1 \% 44,94 (birey sayısına göre) oranında görülmüştür ve toplumun diş aşınma derecesi yoğun olarak 4 ve $4+$ olarak belirlenmiştir (Tablo 2). Tüm lezyonlar değerlendirildiğinde Zeytinli ada toplumunda en yüksek gözlenen oluşumlar sırasıyla önce alveol kaybı daha sonra diş taşı'dır. Bu toplumda en az gözlenen lezyonlar ise çürük ve apse'dir. Çürük ve apsenin az görülmesi bu toplumun besin hazırlama teknikleri ve beslenme alışkanlıklarının iyi olduğunu, karbonhidratlı ve şekerli besinlerin yoğun olarak tüketilmediğini göstermektedir. Genel olarak bakıldığında, Zeytinli ada'dan çıkarılan çene ve dişler genç ve orta erişkin bireylerden oluşur. Farklı dönemlere ait mezarlardan çıkartılan iskeletlere ait dişlerin aşınma dereceleri orta düzeydedir. İleri derecede aşınmaya çok fazla rastlanmamıştır. Bu da beslenmelerinin tarıma dayalı olmakla birlikte, iri ve sert taneli olmadığını düşündürmektedir. Hypoplasia'nın yüksek oranda görülmesi, diş minesinin oluşum sürecinde fizyolojik streslere bağlı olarak ameloblastların aktivitesinde meydana gelen bir aksama nedeniyle, mine kalınlığında ortaya çıkan eksikliğin bir belirtisi olabilir. Diş taş1 oranının çok düşük olmadığı görülmektedir. Bu değerlere göre Zeytinli ada toplumunun ağız ve diş temizliklerine çok özen göstermediklerini düşündürür. Alveol kaybının orta seviyede olması bireylerin ağız bakımının çok da iyi olmadığının bir göstergesidir. İleri derecede aşınma ve çürügün çok fazla olmamasına rağmen, ölüm öncesi diş kaybı oranı yüksek çıkmıştır. Bu durumda diş kaybı oranının yüksek çıkmasının nedeni ilerlemiş yaş olması ihtimalini güçlendirmektedir.

Zeytinli ada toplumunda bebek ve çocuklarda hypoplasia oranı düşük olmasına rağmen erişkin bireylerde hypoplasia oranı yüksek çıkmıştır. Bu durum, toplumdaki erişkin bireylerin bir kısmını, Zeytinli ada içerisinde bulunan şifalı su kaynağını (kaplıca) ziyarete gelen bireyler ile 
Zeytinli adada yerleşik olarak yaşayan bireylerin oluşturmasından kaynaklandığı ihtimalini akla getirmektedir. Zeytinli ada populasyonunu oluşturan bireylerin farklı dönemlerde yaşamış olmalarına karşın diş ve çene patalojileri birbirine benzerlik sunmaktadır. Bu durum, farklı dönemlerde Zeytinli ada da yaşayan insanların aynı yaşam biçimlerine sahip olduklarını göstermektedir. Genelde beslenme rejimlerinin iyi ögütülmüş ancak biraz sert besinlerden oluştuğu, karbonhidratlı ve şekerli besinlerin çok fazla tüketilmediği ve besin hazırlaması sırasında az da olsa aşındırıcı maddelerin karıştığı söylenebilir. Erdek zeytincilik, bağcılık ve şarapçılıkta ekonomik anlamda oldukça ileri gitmiştir. Bu yerleşim yerinin deniz kenarında olması, beslenmede deniz ürünlerine de yer verdiğini düşündürmektedir.

\section{Teşekkür}

Zeytinli adası kazılarına katılma imkanı tanıyan ve iskelet materyallerinin çalışılması konusunda yardımcı olan sayın Doç. Dr. Nurettin ÖZTÜRK'e, çalışmamızın her aşamasında bilgi, öneri ve desteğinden yararlandığımız Sayın Prof. Dr. Ayşen Açıkkol Yıldırım'a, araştırma materyalimizin laboratuvar çalışmaları sırasında bizlere yardımcı olan Büşra Takunyacıoğlu, Serpil Gökdemir, Hüseyin Güleç, Ünsal Karbuz, Çağdaş Erdem'e ve ayrıca araştırmamızı destekleyen Cumhuriyet Üniversitesi Bilimsel Araştırma Projeleri Komisyonuna (CÜBAP, EDB-006, 2011) sonsuz teşekkürlerimizi sunarız.

\section{KAYNAKÇA}

Açıkkol A. (2000) Küçükhöyük Eski Tunç Çağı insanlarının paleoantropolojik açıdan incelenmesi. Ankara: Ankara Üniversitesi Sosyal Bilimler Enstitüsü (Basılmamış Yüksek Lisans Tezi).

Angel JL. (1970) Human skeletal remains at Karataş. American Journal of Archaeology, 74: $253-$ 259.

Atamtürk D, ve Duyar İ. (2008) Adramytteion (Örentepe) iskeletlerinde ağız ve diş sağlığı. $H \ddot{U}$ Edebiyat Fakültesi Dergisi, 25:1-15.

Bouville C, Constandse-Westermann TS, Newell RR. (1983) Les restes humains mesolithiques de l'abri Corneillie 1 stres (Bouches-du Rhone), Bull. Mem.soc.d'Anthro.de Paris 10, Serie XII:89-110

Brothwell DR. (1981) Digging up bones: Excavations, treatment and study of human skeletal remains. Oxford: Oxford University Press.

Buikstra JE, and Ubelaker DH. (1994) Standards for data collection from human skeletal remains. Arkansas: Arkansas Archaeological Survey Research Series.

Erdal YS. (1996) İznik geç Bizans dönemi insanlarının çene ve dişlerinin antropolojik açıdan incelenmesi. Ankara: Hacettepe Üniversitesi Sosyal Bilimler Enstitüsü (Basılmamış Doktora Tezi).

Hillson S. (1990) Teeth. New York: Cambridge University Pres.

Korkmaz D. (1993) Elazı̆̆/Norşuntepe Demir Çağı İskeletlerinde Diş Yapısı ve Hastalıkları. Ankara: Ankara Üniversitesi Sosyal Bilimler Enstitüsü (Basılmamış Yüksek Lisans Tezi).

Küçükkolbaşı H, Kızıloğlu D. (2007) Kompleks odontoma: Olgu Sunumu. SÜ Diş Hekimliği Fakültesi Dergisi, 16: 44-46. 
Ortner DJ, and Putschar GJ. (1985) Identification of pathological conditions in human skeletal remain. Washington: Smithsonian Press.

Özbek M. (1997) Çayönü tarım toplumunda diş sağlı̆̆ı. Türk Arkeoloji Dergisi, Sayı:16.

Özbek M. (2000) Dünden Bugüne İnsan. Ankara: İmge Kitabevi Yayınları.

Özbek M (2007) Dişlerle Zamanda Yolculuk. Ankara: Hacettepe Üniversitesi Yayınları.

Uzel İ, Alpagut B, Kofoğlu S. (1988) Arslantepe Geç Roma Dönemi İskeletlerinde Diş Çürüğü Aşınmaları ve Periodontal Hastalıklar. III. Arkeometri Sonuçları Toplantısı 31-54 Ankara.

Yaşar ZF. (2007) Adli Dental Antropoloji: Dental Antropoloji Açısından Minnetpınarı ve Güllüdere Toplumlarının Dişlerinin Karşılaştırmalı Analizi. Ankara: Ankara Üniversitesi Sosyal Bilimler Enstitüsü. 